\title{
Macrophage Polarization in Chronic Lymphocytic Leukemia: Nurse-Like Cells Are the Caretakers of Leukemic Cells
}

\author{
Oana Mesaros ${ }^{1,2, *}$, Laura Jimbu ${ }^{1,2}$, Alexandra Neaga ${ }^{1}$, Cristian Popescu ${ }^{1,3}{ }^{(\mathbb{D}}$, Iulia Berceanu ${ }^{2}$, \\ Ciprian Tomuleasa ${ }^{1,2}\left(\mathbb{D}\right.$, Bogdan Fetica $^{2}$ and Mihnea Zdrenghea ${ }^{1,2}(\mathbb{D}$ \\ 1 Department of Hematology, Iuliu Hatieganu University of Medicine and Pharmacy, 8 Babes str., \\ 400012 Cluj-Napoca, Romania; ioana.jimbu@umfcluj.ro (L.J.); neaga.alexandra@umfcluj.ro (A.N.); \\ popescu.cristian@umfcluj.ro (C.P.); ciprian.tomuleasa@umfcluj.ro (C.T.); mzdrenghea@umfcluj.ro (M.Z.) \\ 2 Department of Hematology, Ion Chiricuta Oncology Institute, 34-36 Republicii Street, \\ 400015 Cluj-Napoca, Romania; iuliaberceanu@yahoo.com (I.B.); feticab@yahoo.com (B.F.) \\ 3 Department of Infectious Diseases, County Emergency Hospital Alba Iulia, 20 Decebal str., \\ 510093 Alba-Iulia, Romania \\ * Correspondence: mesaros.oana@umfcluj.ro; Tel.: +40-741-237-703
}

Received: 14 September 2020; Accepted: 17 November 2020; Published: 19 November 2020

\begin{abstract}
Macrophages are terminally differentiated innate immune cells. Through their activation, they can be polarized towards the pro-inflammatory M1 type or the wound healing-associated, anti-inflammatory M2 type macrophages. In the tumor microenvironment (TME), M2 is the dominant phenotype and these cells are referred to as tumor-associated macrophages (TAMs). TAMs secrete cytokines and chemokines, exerting an antiapoptotic, proliferative and pro-metastatic effect on the tumor cells. TAMs can be found in many cancers, including chronic lymphocytic leukemia (CLL), where they are called nurse-like cells (NLCs). Despite the generally indolent behavior of CLL, the proportion of treatment-refractory patients is significant. As with the majority of cancers, despite significant recent progress, CLL pathogenesis is poorly understood. The emerging role of the TME in nurturing the neoplastic process warrants the investigation of macrophages as a significant pathogenetic element of tumors. In this paper, we review the current knowledge on the role of stromal macrophages in CLL.
\end{abstract}

Keywords: macrophages; CLL; nurse-like cells

\section{Introduction}

Every second our body goes through changes. Millions of cells are dying and are being replaced by new ones, especially in the tissues that are most exposed to environmental wear, such as the immune system. To accomplish its function, the immune system increases its turnover during infections, inflammation or tissue damage. The macrophages have a crucial role in initiating the inflammatory response, tissue homeostasis and repair [1,2], but, on the other hand, they play a part in the development of various diseases including cancer [2]. Along with vascular endothelial cells, fibroblasts and other immune cells, a subtype of functionally altered macrophages are part of the tumor microenvironment (TME), setting up the stage for tumor genesis and metastases, promoting genetic instability and tempering anticancer immunity [3]. These types of macrophages are called tumor-associated macrophages (TAMs), and their implication has been proved in different types of cancer [4], including leukemia [5].

Chronic lymphocytic leukemia (CLL) is mostly a disease of the elderlyand is commonly referred to as the most frequent of leukemias in the Western world. According to the World Health 
Organization classification, CLL, together with its solely tumoral presentation, the small lymphocytic lymphoma (SLL), belongs to the mature B cell neoplasms category, along with other non-Hodgkin's lymphomas [6].Its manifestations range from mild, in the majority of patients, to aggressive, and the therapeutic approach varies from a watch and wait attitude, to the immediate need for treatment initiation [7]. Over time, a plethora of prognostic markers have been established for CLL, starting with the Rai and Binet staging systems, still in use for almost half a century [8,9], continuing with cytogenetic abnormalities like trisomy 12, del 13q14, del 11q22.3-q23.1, del 17p [10], mutational status of the variable part of the immunoglobulin heavy chain [11], and other recurrent mutations (TP53, NOTCH1, BIRC3, MYD88 etc.) [12,13]. More recently, microRNA profiling, TME characteristics, and the nurturing capacity of TAMs towards leukemic cells have been studied in this regard $[2,3,14,15]$.

TAM infiltration has been associated with outcomes in several cancers including breast cancer, gastric cancer and pancreatic neuroendocrine tumors [16-18]. The present review focuses on macrophages' characteristics in CLL, on the way they influence tumorigenesis, and on their pathogenetic potential and prognostic significance.

\section{What Are Macrophages?}

Macrophages are terminally differentiated innate immune cells. Their surface membrane receptors and cytokine/chemokine production orchestrate their role in homeostasis, initiation and resolution of inflammatory processes, clearance of apoptotic bodies or other debris and last, but not least, tissue remodeling and repair [19-21].

The macrophages were described in the late 19th century, by Ilya Metchnikoff, a Russian zoologist, who was intrigued by this type of mobile cells, acting as a sentinel, able to attack, engulf and destroy the invading pathogens [22]. Following the path that the Russian scientist opened, van Furth suggested that tissue macrophages have their origin in circulating adult monocytes [23], coining the term "mononuclear phagocyte system". It is presently accepted that, based on their origin, there are two types of macrophages: blood monocyte-derived macrophages (MDMs) and tissue-resident ones [24].

Blood monocyte development takes place in the bone marrow, from the hematopoietic stem cells (HSCs), under the influence of growth factors like granulocyte-macrophage colony-stimulating factor (GM-CSF). Once they reach their adulthood, they migrate into the bloodstream and remain there for up to 2 days. During this time, stimulated by specific cytokines and chemokines, they can migrate to different tissues and differentiate into macrophages, providing the restoration of the tissue macrophage pool whenever and wherever it is needed; alternatively, they undergo apoptosis or programmed cell death, consecutively being removed from the circulation [25].

Some of the tissue-resident macrophages do not develop from blood monocytes, but they emerge during the first week of gestation from the yolk sac and migrate to the fetal liver, a primary hematopoietic organ until the bone marrow is ready to overtake this function. They then migrate and populate the respective tissues [26,27]. Tissue macrophages are present in most organs, exhibiting various phenotypes, morphologies, functions and names, according to the anatomic site [24], and have a low turnover during steady-state which is increased during inflammatory processes [1]. Some of the tissue macrophages have an independent self-renewal potential, but the rest of the tissular pool is being subsequently replenished by MDMs [28]. The replenishing of tissue macrophages is regulated by the colony-stimulating factor-1 receptor (CSF-1R), colony-stimulating factor-1 (CSF-1), known as the macrophage-colony-stimulating factor (M-CSF), interleukin-34 (IL-34) and monocyte chemoattractant protein 1 (MCP-1) or C-C motif ligand 2 (CCL-2) [29].

\section{Activation of Macrophages}

When there is a stimulus, like inflammation, infection, debris, or apoptotic bodies, the macrophages are activated and their phenotype changes through the classical or alternative pathways. The outcome of the classical activation will result in the M1 subtype, representing the pro-inflammatory macrophages, and the alternative pathway will lead to the formation of M2 macrophages, which are the 
anti-inflammatory ones. The paradigm of the M1/M2 subtypes was suggested as a parallel to the T-helper 1 (Th1) and T-helper 2 (Th2) cells [30,31]. Polarization occurs during the macrophage activation process and is controlled by three variables: microenvironment, cytokines and epigenetics [32]. The classical activation of macrophages (M1) takes place under the aegis of Th1 type cytokines like interferon-gamma (IFN- $\gamma$ ) and lipopolysaccharide (LPS), through a glycolytic track [33,34]. Along with the cytokines, transcription factors like the signal transducer and activator of transcription 1 (STAT-1), the nuclear factor kappa B (NF-kB), the activator protein 1 (AP-1), the interferon regulatory factor 5 (IRF-5), influence M1 polarization [35-38]. After the activation, the cells will express markers like CD68, CD80, CD89 $[39,40]$ and will exert their action by releasing pro-inflammatory cytokines, such as tumor necrosis factor- $\alpha$ (TNF- $\alpha$ ), IL-6, IL-1, IL-12, IL-23, inducible nitric oxide synthase (iNOS), MCP-1 (Figure 1) [41].

The alternative pathway (M2) is triggered by various cytokines, the most important being IL-4 and IL-13, which are Th2 type cytokines, and is, energy-wise, fueled through fatty acid oxidation [33,34]. M2 macrophages were further classified into four subcategories: M2a, M2b, M2c [30,42] and M2d [43,44]. M2a is triggered by the effect of IL-4 and IL-13 and releases cytokines like IL-10, CCL13, CCL17, and CCL22, M2b is activated by LPS or IL-1 $\beta$ and produces IL-10, CCL1, IL-12, M2c is stimulated by Il-10 and discharges CCL 16 and CCL 18 chemokines. The M2d type is credited by some authors as TAMs, is stimulated by IL-6, M-CSF and the activation of the adenosine receptors and releases high amounts of IL-10, TGF- $\beta$, VEGF, CCL5, CXCL10, CXCL16 and low levels of IL-12 (Figure 1). M2 activation also depends on transcription factors, such as STAT-6, IRF-4, hypoxia inducible factor-1 alpha (HIF-1 $\alpha)$, peroxisome proliferator-activated receptor gamma (PPAR- $\gamma$ ), CCAAT/enhancer-binding proteins $(\mathrm{C} / \mathrm{EBP} \beta)$ [45-49]. The immunophenotyping of M2 macrophages reveals the presence of markers such as CD64, CD163, CD200, CD206, CD209 [39,40,50].

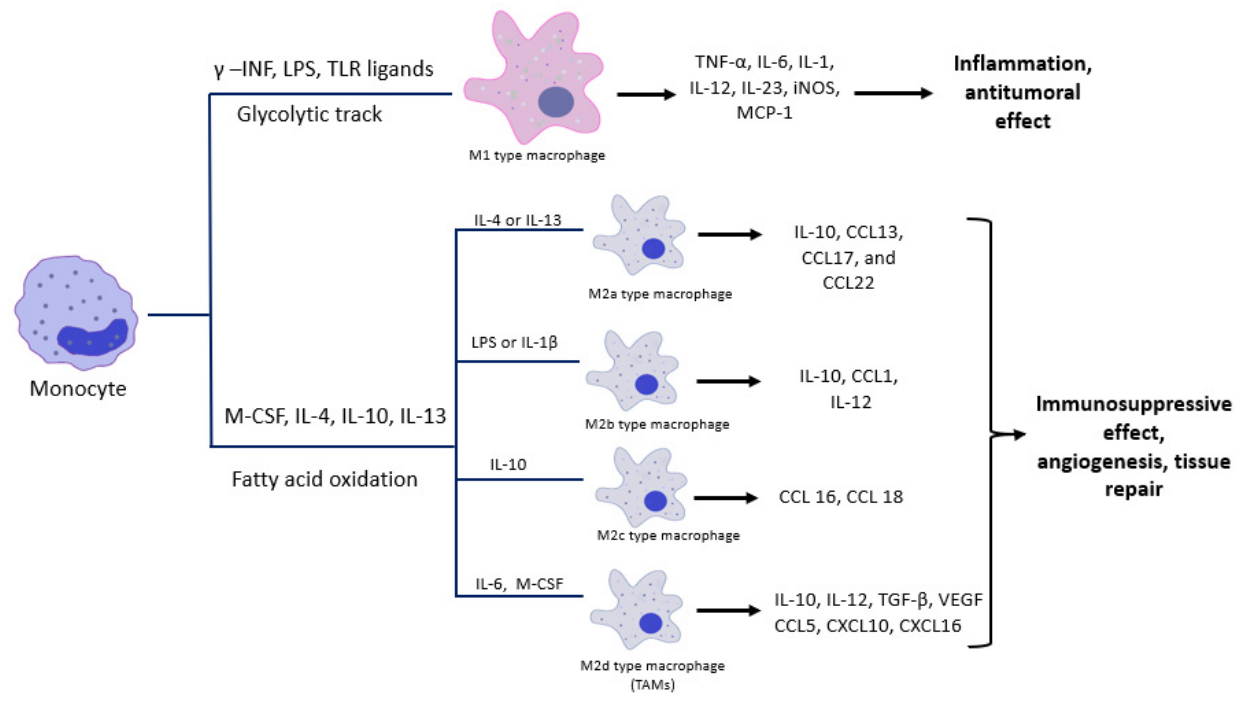

Figure 1. The classical (M1) and the alternative (M2) macrophage activation and their effect on the involved tissues.

In contrast to M1 macrophages, the M2 subtype exerts, as mentioned before, a healing effect and will release cytokines into circulation like vascular endothelial growth factor (VEGF), transforming growth factor- $\beta$ (TGF- $\beta$ ), epidermal growth factor (EGF), and arginase [1,14]. Furthermore, M1 cells produce iNOS, which stimulates the production of nitric oxide (NO), while the M2 subtype produces TGF- $\beta$, an NO inhibitor. Additionally, M1 polarization uses STAT-1 as a transcription factor, while M2 polarization uses STAT-6. These two pathways are mutually exclusive.

The complete mechanism of macrophage polarization is not yet fully understood, but in vitro studies on human macrophages have shown that serotonin or 5-hydroxytryptamine (5-HT) may also have an important role in this activation process [51]. This substance is known for its role as a 
neurotransmitter, but, in recent years, its immunomodulatory role has been discovered. Most of it is secreted by the enterochromaffin cells in the intestine, transported into the bloodstream, collected by the platelets and released during their activation (thrombus, inflammation) [52]. As an immunomodulatory substance, it coordinates the cytokine discharge from the macrophages and monocytes, suppressing TNF- $\alpha$ and IL- $1 \beta$ and promoting the macrophage polarization towards M2 subtype, thus stimulating the growth and regeneration of the tissue [53].

The M1 and M2 pathways are antithetic: while one destroys, the other repairs and an imbalance between these pathways could lead to the appearance of autoimmune diseases, metabolic instability and even cancer. This dichotomous model, proposed in 2000 by Charles Mills [31] has since evolved to accept the occurrence, in vivo, of a continuum of macrophage phenotypes situated between the two polarized states [54].

\section{The Macrophages and Cancer}

The TME contains a plethora of immune cells, including macrophages ( 50\%) [55], which are attracted by high amounts of lactic acid and certain cytokines and subsequently converted into TAMs [56]. Occasionally, these cells are regarded as equivalent to M2 macrophages, but some authors have reported that even though TAMs mostly have M2 characteristics, they may also share some of the M1 phenotype's functions [57]. The heterogeneity and plasticity of TAMs allow them to satisfy the need of any tumor, receiving "instructions" based on the tumoral tissue's type [58]. In some types of neoplasia, the high rate of TAMs infiltrating the TME correlates with a worse disease outcome, as TAMs release cytokines that promote the immune escape, the anti-apoptotic effect, the growth, the metastasis and the chemoresistance of the tumor cells [59].

TAM differentiation is orchestrated by cytokines released from the stromal and tumor cells [60]. The accelerated tumor metabolism and growth, without the required vascular sustenance, generates hypoxia. Thus, along with lactic acid, chemokines including, but not limited to CSF-1, CCL-2, CCL-5, VEGF, are released, and macrophages are attracted to the TME [56,61]. Here, under the action of IL-6, IL-10, IL-12, TNF, CCL-2, CCL-5, CSF-1and the overexpression of epidermal growth factor receptor (EGFR), macrophages undergo an M2 like polarization and become TAMs [62,63]. Several murine and human studies have proven that the depletion of CSF-1, CCL-2, VEGF and EGFR lowered the TAMs infiltration, and, implicitly, tumor progression and metastasis [63-65]. Cytokines like TNF- $\alpha$, IL-1 $\beta$, IL-6, IL-8, IL-10, TGF- $\beta$, stimulate epithelial-mesenchymal transition (EMT) [66-71], by which tumor cells gain multi-directional differentiation and self-renewal potential, and the ability to migrate and invade tissues, creating an ideal background for treatment resistance in tumors [72,73].

\section{TAM-Related Cytokines and Chemokines}

\section{1. $T N F-\alpha$}

TNF- $\alpha$ is largely produced by macrophages and exerts its role as an inflammation mediator. Usually, TNF- $\alpha$ through its receptors, TNFR-1 and TNFR-2, activates Janus kinase (JAK) and NF- $\mathrm{kB}$ signaling pathways and further regulates cell proliferation, survival, differentiation and, finally, apoptosis [74]. When it comes to neoplasia, TNF- $\alpha$ has an ambivalent role, as it could be both an enhancer and a tamer of cancer. Studies have proven that at high doses, TNF- $\alpha$ induces tumor cell apoptosis and stimulates anti-tumor immunity, while at low doses, it helps tumor growth, metastasis and the EMT, in both murine and human models [75,76]. However, the exact mechanism of action is still debatable, but it could involve the TNFR-1 and TNFR-2 distribution, and, of course, the tumor location and stage $[77,78]$. In CLL, TNF- $\alpha$ is constitutively produced by the CLL B cells and carries an antiapoptotic role and sustains tumor proliferation. Higher levels of TNF- $\alpha$ have been correlated to more aggressive disease $[79,80]$. 


\section{2. $I L-1 \beta$}

IL-1 $\beta$, also known as mononuclear cell factor (MCF), lymphocyte-activating factor (LAF) or endogenous pyrogen (EP) [81] is another cytokine with divergent activity. Commonly it is considered to be one of the most powerful enhancers of inflammation, as it stimulates the innate immune cells and promotes the polarization of $\mathrm{T}$ cells towards Th1 and Th17 phenotypes, exerting its role in adaptive anti-tumor immunity. However, released by the TAMs in the TME, IL- $1 \beta$ has an opposite role, supporting EMT, tumor growth and anti-apoptosis [82-84]. As well as TNF- $\alpha$ and IL-6, IL-1 $\beta$ exerts it pro-tumoral function through the NF-kB and mitogen-activated protein kinase (MAPK) and other signaling pathways like protein kinase B (AKT) or Wingless (WNT) [85-87]. High levels of IL-1 $\beta$ are correlated with bad prognosis [88].In the context of CLL, IL-1 is produced by the B CLL cells and induces differentiation and activation of neoplastic cells [89]. However, in the serum of CLL patients, high levels of IL-6 were associated with low levels of IL-1 $\beta$, which seems to lead to the development of tumor cells [90].

\subsection{IL-6}

IL-6 is a cytokine produced by the immune cells, especially by macrophages. By binding the IL-6R and activating STAT 3 phosphorylation, it exerts its pro-tumoral effects (anti-apoptotic, immunosuppression, angiogenic, metastatic) [91] and apparently, it promotes EMT, as well [69,92], possibly promoting the tumor development and self-renewal of malignant cells. IL-6 and cancer stem cells stimulate one another. For example, in glioma, via the MYD88-TLR4 pathway, glioma stem cells stimulate the TAMs to produce IL-6, which, in turn, will stimulate the EMT via the JAK/STAT3/Snail pathway. This positive feed-back trail will support and nurture glioma development [93]. Higher levels of IL-6 have been correlated to worse disease outcomes [94]. To our knowledge, in CLL, TAMs do not produce Il-6, but in turn they strongly influence its autocrine production by the CLL cells $[95,96]$. In CLL, IL-6 can be correlated to a poor disease outcome, as it holds a pro-tumorigenic effect as well [97].

\section{4. $I L-10$}

IL-10 is an anti-inflammatory cytokine, mainly secreted by macrophages, but also by neoplastic cells, in hypoxia conditions [98]. IL-10 exerts its role by binding to its receptor and blocking the anti-tumor immunity, inhibiting pro-inflammatory cytokines like IFN- $\gamma$, IL-6, IL-8, IL-12, IL-1 $\beta$ and TNF- $\alpha$, suppressing the M1 polarization, and restraining the major histocompatibility complex II (MHC II) molecule on the surface of the macrophages [99]. It also activates STAT3 phosphorylation, promoting anti-apoptotic, immunosuppressive, angiogenic and metastatic reactions [100]. IL-10 protects the tumor, while inhibiting the chemotaxis of neutrophils, monocytes and dendritic cells in the TME, by suppressing the CC and CXC chemokines [101]. Promoting EMT is another way of nurturing the tumor. In vivo studies on mice models have shown that IL-10 seems to be one of the pillars of EMT and of obtaining the stemness of tumor cells [102,103]. Treatments based on inhibitory molecules of IL-10 are currently being studied. In CLL, IL-10 is also associated with treatment resistance and immune suppression. This cytokine has an important role in the resistance of CLL cells to ibrutinib. Apparently, ibrutinib targets Bruton's tyrosine kinase from the surface of TAMs from the CLL microenvironment, modifying their function and stimulating them to produce IL-10, providing the tumor cells with resistance to treatment [104]. B CLL cells also produce IL-10, through the stimulation of B-cell receptor (BCR), in murine and human studies [105].

\subsection{TGF- $\beta$}

TGF- $\beta$ is a cytokine with a dual role in tumor evolution, promoting and inhibiting it as well. There are three types of TGF- $\beta$, but TGF- $\beta 1$ is the most often implicated in tumorigenesis. The TGF- $\beta$ ligands exert their role through binding TGF $\beta$ R1 or TGF $\beta R 2$ [106]. In the incipient tumor stage, it acts as a tumor suppressor, by inducing apoptosis, inhibiting the tumor cell proliferation and favoring their 
differentiation towards healthy cells. In late tumor stages, it has a tumor promoting role, stimulating EMT, immunosuppression, angiogenesis, tumor cells self-renewal and chemo-resistance [107,108]. Using TGF- $\beta$ as a target in cancer treatment is still controversial, as it needs further clinical trials [109]. In CLL patients' serum, large quantities of TGF- $\beta$ are found, but despite this, the neoplastic cells develop a resistance to this cytokine's pro-apoptotic effect [110]. Further, the leukemic cells produce TGF- $\beta$ that stimulates the growth of TAMs, which will nurture the tumor itself [111].

\subsection{CCL2}

CCL-2 or MCP-1 is a chemokine from the C-C chemokine family, with an important role in recruiting macrophages to the TME and EMT. Tumor cells are the main source of CCL-2, but it can be also secreted by non-tumor cells [112]. By binding CCR-2, CCL-2 promotes tumor growth and metastasis. In vitro studies on human lung squamous cell carcinoma and lung adenocarcinoma cells have correlated the high levels of CCL-2 with worse disease prognosis [113]. The inhibition of the CCL2-CCR2 complex or CCL2 or CCR2 alone, has provided a lowering in tumor growth and prolonged survival in some cancers, giving another opportunity to evaluate a new cancer treatment $[114,115]$. The CCL2 level is high in the serum of CLL patients. The presence of this cytokine will help create a microenvironment that will be able to protect the tumor cells against apoptosis and will stimulate its progression [116].

\section{Macrophages in CLL}

CLL is a heterogenous hematologic disease, characterized by the accumulation of mature lymphocyte-like malignant cells in the bone marrow, peripheral blood, lymph nodes (LN) and spleen. Usually, it behaves as a mild, slowly progressive disease, but in a proportion of cases, a more aggressive, sometimes violent evolution and chemoresistance are observed. Research has focused on finding the background for CLL cells increasing their proliferation rate, enhancing their anti-apoptotic features, and their resistance to treatment. Studies on in vitro cultured CLL cells have shown that the accelerated proliferation and the low rate of apoptosis are not independent cell abilities, but are linked to the TME $[117,118]$. Hence, a closer look to the CLL TME was necessary, which led Burger et al. to observe that the CLL microenvironment contains a population of mononuclear cells exhibiting common features with the thymic nurse cells, and release mediators that prevent the apoptosis of CLL cells in vitro [111]. Later in vivo and in vitro studies in CLL patients have proven that these cells can be found in the secondary lymphoid tissues and that they are TAM correspondents in CLL [119-122]. TAMs can be observed in different types of solid tumors, holding particular phenotypes and producing cytokines and chemokines according to the lineage of the neoplastic cells. They are usually correlated with a worse disease outcome. Such cells are encountered in leukemias as well, where they are called leukemia-associated macrophages (LAMs) [14]. The LAMs in CLL are known as nurse-like cells (NLCs) [111]. They are positively correlated with peripheral blood monocytes and serum beta 2 microglobulin levels [15] and their abundance was linked to an adverse prognosis, like in the case of other TAMs [123].

NLCs derive from blood monocytes under the influence of CLL cells and in return, they release chemokines, like C-X-C motif ligand 12 and 13 (CXCL12 and CXCL13) to attract even more CLL cells [111]. They have an M2 like phenotype, expressing on their surface, markers like CD14, CD11b, CD68, CD163 and HLA class II [124]. Once in the right place, NLCs support CLL cells by enhancing their proliferation, survival, invasion and metastasis, and by disrupting the anti-tumoral immunity.

\section{NLC Functions}

\subsection{Recruiting Cells}

The CLL cells express functionally active chemokine receptors such as CXCR3, CXCR4 and CXCR5 that enable their migration and homing process. Normal B cells usually express CXCR4 and CXCR5, while CXCR3 is found on a small number of CD5+ and negative B lymphocytes. 
CXCR3 is expressed by $\mathrm{CD} 4^{+} \mathrm{CD} 8^{+}$and activated $\mathrm{T}$ cells and by NK cells, binds its ligands CXCL9, CXCL10, CXCL11 and helps trafficking activated T lymphocytes, dendritic and NK cells to the inflammation site. During homeostasis periods, CXCL9, CXCL10, CXCL11 are produced in small quantities by endothelial cells, fibroblasts and monocytes, with their secretion being up-regulated under the effect of IFN $-\gamma$ and TNF- $\alpha$ [125-127].

In CLL, chemokines CXCL9, CXCL10, CXCL11 are produced by TME components, including NLCs $[125,127]$. The axis CXCR3-CXCL9/CXCL10/CXCL11 has a chemotactic role for CLL cells (Figure 2) [120]. CXCR3 expression levels are variable and low levels are associated with advanced disease and poor prognosis in CLL [128].

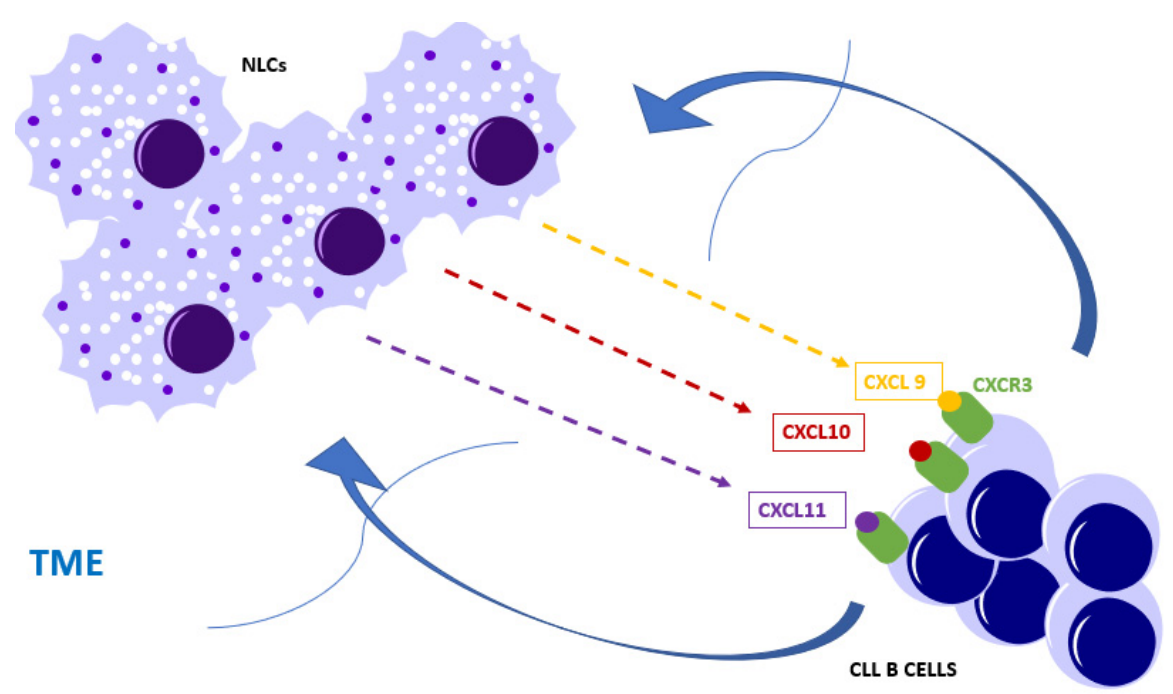

Figure 2. Nurse-like cells (NLCs), along with endothelial cells, fibroblasts and monocytes, secrete chemokines like CXCL9, CXCL10, CXCL11, which will bind the CXCR3 receptor expressed on the chronic lymphocytic leukemia (CLL) B cells and attract the cells into the tumor microenvironment (TME).

CXCR4 is expressed on both CLL B cell-like and normal B cells, but its expression appears to be five times higher in the former [129]. CXCR4's ligand is called stromal cell-derived factor-1 (SDF-1) or CXCL12 and is a chemokine secreted by the bone marrow stromal cells, under the control of TGF $\beta 1$ and HIF-2 $\alpha$. The CXCR4-CXCL12 axis influences the homing in the bone marrow of the CLL cells and their interactions with stromal cells, favoring their adhesion to the stroma, and thus their chemoresistance $[111,130]$. NLCs also secrete CXCL12, enabling the chemotaxis of CLL cells through the endocytosis of CXCR4 [119,129], a process that will imply the down-regulation of the CXCR4 expression level after the migration [111]. High expression of CXCR4 is correlated with an advanced stage of CLL [131].

CXCR5 is usually expressed on the surface of mature B cells, a small fraction of T cells, and a type of skin-derived dendritic cells [132]. Its ligand is known as CXCL13 or B-cell-attracting chemokine 1 (BCA-1) and is secreted by the stromal cells within the lymphoid follicles. The axis CXCR5-CXCL13 stimulates the recruitment of naïve $B$ cells within the germinal center of the lymphoid follicles. As the CLL B cells highly express CXCR5, through a chemokine gradient, they are attracted by the secretion of CXCL13, from the tumor stromal cells and NLCs. The binding of CXCR5 and CXCL13 stimulates the endocytosis of the receptor, the formation of actin polymers, the activation of ERK1/2 (extracellular signal-regulated protein kinases 1 and 2) and the migration and homing of the CLL cells to the LNs, where they are defended against apoptosis $[125,133,134]$.

Apart from these, in vitro studies have revealed that NLCs co-cultured with purified CD19+ CLL cells, induce, through B-cell receptor (BCR) activation, the production of T lymphocytes-specific chemokines: CCL 3 and CCL 4 . Through their receptors, CCR 1 and CCR 5, they recruit T cells and 
other leukocytes, including some NLCs precursors. The CCL 3 and CCL 4 levels correlate with the zeta-associated protein 70 (ZAP-70) expression on the CLL cells surface [135].

\subsection{Enhancing Survival and Antiapoptotic Effect}

It can be asserted that NLCs sustain and improve CLL cells survival, as it was observed that patients with lower NLCs levels have better overall survival [120]. Through the activation of the BCR and NF-kB pathways, NLCs exert an antiapoptotic effect on CLL cells, enhancing their survival [136].

As the BCR pathway is initiated, enzymes and adaptor molecules, including the spleen tyrosine kinase (Syk), are activated and phosphorylate Bruton tyrosine kinase (BTK) and phosphoinositol-3 kinase (PI3K). The phosphorylated BTK and PI3Kwill eventually lead to the activation of NF-kB, RAS and MAP kinases pathways [125,137], which will impair the anti-tumoral immunity, providing an antiapoptotic effect and enhancing the survival of CLL cells.

Another way of activating the NF-kB pathway is through the release of B cell activating factor (BAFF) and a proliferation-inducing ligand (APRIL), by the NLCs and other stromal cells [138]. BAFF and APRIL are both TNF family members and are usually expressed by monocytes, macrophages, dendritic cells and T cells. They bind BAFF-R, TNFR homolog transmembrane activator and CAML interactor (TACI) and B cell maturation antigen (BCMA) receptors found on B cells [137], and finally, will activate downstream NF-kB pathways.

CD40L (ligand), another TNF family member, is usually expressed on the surface of T cells. In a physiological context, the CD40L would bind the CD40 receptor expressed on the B cells and would regulate cell differentiation [137]. However, CLL B cells possess an aberrant expression of CD40L, which promotes CLL cells survival and differentiation. The aberrant expression of CD40L is up-regulated by the presence of APRIL and BAFF, which are stimulated by the activation of the CCL2-CCR2complex [125,138]. CCL2 gene is highly expressed on NLCs [120]. Although it appears not to have a direct effect on CLL cells, the CCL2-CCR2 complex attracts more monocytes to the TME and stimulates the NLCs to release factors like BAFF and APRIL, building up the anti-apoptotic effect, tumor progression and metastasis [111,139].

CD38 and ZAP-70, members of the Syk family, are both correlated with a bad outcome for CLL patients [140]. ZAP-70 is usually present on the surface of T and NK cells, but not on normal B cells. However, CLL cells also possess this marker, and it appears that CD 38 binds with CD31 ligand, expressed by NLCs and leads to ZAP-70 phosphorylation, which will further activate the BCR and through signaling pathways like PI3Ks and BTK will enhance CLL cells proliferation and survival [141].

Another important cytokine involved in immune suppression and CLL cell survival is IL-10. In vitro studies on CLL patients' serum and in vivo studies on mice models have revealed that IL-10 is found in larger quantities in CLL patients' serum, than in healthy controls [105,142]. IL-10 is a suppressor type 2 cytokine that inhibits $\mathrm{MCH}$ class II on the surface of APC, limiting the antitumoral immunity [143]. Apart from the CLL cells chemotaxis mentioned above, CXCL12-CXCR4, regulates the levels of IL-10, through STAT3 pathway. In vitro studies on CLL patients' serum have revealed that inhibition of STAT3 phosphorylation down-regulates IL-10 and reinforces anti-tumoral immunity [144].

After inhibiting the above mentioned antiapoptotic factors in co-cultures of CLL cells, some of these cells survive, meaning that they have other ways of evading the apoptosis. Based on this assumption, in 2018, Abbaciet al. published an article about the effect of brain-derived neurotrophic factor (BDNF) on CLL cells. BDNF's expression is high on the surface of CLL cells and by binding the neurotensin receptor 2-tropomyosin-related kinase receptor B (NTSR2-TrkB) complex which is highly expressed on CLL cells surface as well, activates B-cell lymphoma 2 protein (BCL-2) and other signaling pathways, leading to an anti-apoptotic effect [145]. Recent in vitro studies on CLL patients' cells suggest that BDNF is in fact secreted by the NLCs [146].

Apart from secreting and stimulating cytokine and chemokine production, NLCs may also provide an antiapoptotic effect through their direct interactions with the CLL cells. CD2 expressed on the surface of NLCs, binds the lymphocyte function-associated antigen 3 (LFA-3) or CD 58, expressed 
on CLL cells, inhibiting their programmed death. It also seems that LFA-3 produces soluble LFA-3 (sLFA-3), which may inhibit the T-cell immune response, once again helping the CLL cells to evade immune control. In a study which included 60 chemoimmunotherapy-treated CLL patients, the levels of sLFA-3 were correlated with shorter overall survival [147].

\subsection{Proliferation Stimulation}

CLL cell proliferation occurs in the pseudo-follicles, which are proliferation centers found in the LNs and BM that contain lymphocytes and prolymphocytes. In the LNs, the CLL cells have the first contact with antigens and also receive proliferation and antiapoptotic signals [148-150].

The proliferation rate of CLL cells depends on the cell characteristics, but it seems that, in a small part, NLCs have some implication in this process. For example, CD38 ${ }^{+}$cells have a higher Ki-67 expression [151] and proliferate much faster than CD38 ${ }^{-}$cells [152]. CD38 is a membrane protein, with a higher expression in the BM and secondary lymphoid organs [153], and, as mentioned before, represents a negative prognostic factor for CLL patients. CD38 binds its ligand, CD31, which is expressed by the stromal cells and NLCs $[153,154]$ and stimulates the ZAP-70 phosphorylation and further on, it activates BCR and other signaling pathways that will lead to the proliferation of CLL cells [141,155]. The presence of CD38 and ZAP-70 appears to be synergic [154].

\section{Conclusions}

TAMs, known as NLCs in CLL, are part of the TME and resemble M2 polarized macrophages, witha pro-tumorigenic effect, while the M1 subtype holds a pro-inflammatory, anti-neoplastic effect. In some types of neoplasia, the TAM infiltration level was correlated with a dismal prognosis, but this was not yet proved when it comes to CLL. We know that isolated in vitro cultured CLL cells die, but co-cultured with the NLCs, they are able to proliferate, suggesting that a clue for CLL cure may lie not only in the tumor cell characteristics, but in the particularities of the TME as well. A better understanding of the TME could allow for the development of new and more effective antineoplastic therapies targeted at its modulation. This could be a key element towards a personalized cancer therapy, with better tolerance and less adverse effects, compared to the classical chemotherapy approach.

The road is indeed arduous and long, but the promise that we will be able to personalize the treatment for diseases such as CLL, to expand the overall survival and the treatment-free survival for these patients should provide enough fuel to carry on the research and enrich the knowledge we have obtained so far.

Funding: This research received no external funding.

Conflicts of Interest: The authors declare no conflict of interest.

\section{References}

1. Funes, S.C.; Rios, M.; Escobar-Vera, J.; Kalergis, A.M. Implications of macrophage polarization in autoimmunity. Immunology 2018, 154, 186-195. [CrossRef]

2. Wynn, T.A.; Chawla, A.; Pollard, J.W. Macrophage biology in development, homeostasis and disease. Nature 2013, 496, 445-455. [CrossRef] [PubMed]

3. Quail, D.F.; Joyce, J.A. Microenvironmental regulation of tumor progression and metastasis. Nat. Med. 2013, 19, 1423-1437. [CrossRef] [PubMed]

4. Larionova, I.; Cherdyntseva, N.; Liu, T.; Patysheva, M.; Rakina, M.; Kzhyshkowska, J. Interaction of tumor-associated macrophages and cancer chemotherapy. Oncoimmunology 2019, 8, 1596004. [CrossRef] [PubMed]

5. Chen, S.Y.; Yang, X.; Feng, W.L.; Liao, J.F.; Wang, L.N.; Feng, L.; Lin, Y.M.; Ren, Q.; Zheng, G.G. Organ-specific microenvironment modifies diverse functional and phenotypic characteristics of leukemia-associated macrophages in mouse T cell acute lymphoblastic leukemia. J. Immunol. 2015, 194, 2919-2929. [CrossRef] 
6. Swerdlow, S.H.; Campo, E.; Pileri, S.A.; Harris, N.L.; Stein, H.; Siebert, R.; Advani, R.; Ghielmini, M.; Salles, G.A.; Zelenetz, A.D.; et al. The 2016 revision of the World Health Organization classification of lymphoid neoplasms. Blood 2016, 127, 2375-2390. [CrossRef]

7. Hallek, M. Chronic lymphocytic leukemia: 2020 update on diagnosis, risk stratification and treatment. Am. J. Hematol. 2019, 94, 1266-1287. [CrossRef]

8. Rai, K.R.; Sawitsky, A.; Cronkite, E.P.; Chanana, A.D.; Levy, R.N.; Pasternack, B.S. Clinical staging of chronic lymphocytic leukemia. Blood 1975, 46, 219-234. [CrossRef]

9. Binet, J.L.; Auquier, A.; Dighiero, G.; Chastang, C.; Piguet, H.; Goasguen, J.; Vaugier, G.; Potron, G.; Colona, P.; Oberling, F.; et al. A new prognostic classification of chronic lymphocytic leukemia derived from a multivariate survival analysis. Cancer 1981, 48, 198-206. [CrossRef]

10. Dohner, H.; Stilgenbauer, S.; Dohner, K.; Bentz, M.; Lichter, P. Chromosome aberrations in B-cell chronic lymphocytic leukemia: Reassessment based on molecular cytogenetic analysis. J. Mol. Med. (Berl.) 1999, 77, 266-281. [CrossRef]

11. Damle, R.N.; Wasil, T.; Fais, F.; Ghiotto, F.; Valetto, A.; Allen, S.L.; Buchbinder, A.; Budman, D.; Dittmar, K.; Kolitz, J.; et al. Ig V gene mutation status and CD38 expression as novel prognostic indicators in chronic lymphocytic leukemia. Blood 1999, 94, 1840-1847. [CrossRef] [PubMed]

12. Puente, X.S.; Pinyol, M.; Quesada, V.; Conde, L.; Ordonez, G.R.; Villamor, N.; Escaramis, G.; Jares, P.; Bea, S.; Gonzalez-Diaz, M.; et al. Whole-genome sequencing identifies recurrent mutations in chronic lymphocytic leukaemia. Nature 2011, 475, 101-105. [CrossRef] [PubMed]

13. Rossi, D.; Fangazio, M.; Rasi, S.; Vaisitti, T.; Monti, S.; Cresta, S.; Chiaretti, S.; Del Giudice, I.; Fabbri, G.; Bruscaggin, A.; et al. Disruption of BIRC3 associates with fludarabine chemorefractoriness in TP53 wild-type chronic lymphocytic leukemia. Blood 2012, 119, 2854-2862. [CrossRef] [PubMed]

14. Li, Y.; You, M.J.; Yang, Y.; Hu, D.; Tian, C. The Role of Tumor-Associated Macrophages in Leukemia. Acta Haematol. 2020, 143, 112-117. [CrossRef] [PubMed]

15. Filip, A.A.; Cisel, B.; Wasik-Szczepanek, E. Guilty bystanders: Nurse-like cells as a model of microenvironmental support for leukemic lymphocytes. Clin. Exp. Med. 2015, 15, 73-83. [CrossRef]

16. Qiu, S.Q.; Waaijer, S.J.H.; Zwager, M.C.; de Vries, E.G.E.; van der Vegt, B.; Schroder, C.P. Tumor-associated macrophages in breast cancer: Innocent bystander or important player? Cancer Treat. Rev. 2018, 70, 178-189. [CrossRef]

17. Szulczewski, J.M.; Inman, D.R.; Entenberg, D.; Ponik, S.M.; Aguirre-Ghiso, J.; Castracane, J.; Condeelis, J.; Eliceiri, K.W.; Keely, P.J. In Vivo Visualization of Stromal Macrophages via label-free FLIM-based metabolite imaging. Sci. Rep. 2016, 6, 25086. [CrossRef]

18. Grossman, J.G.; Nywening, T.M.; Belt, B.A.; Panni, R.Z.; Krasnick, B.A.; DeNardo, D.G.; Hawkins, W.G.; Goedegebuure, S.P.; Linehan, D.C.; Fields, R.C. Recruitment of CCR2(+) tumor associated macrophage to sites of liver metastasis confers a poor prognosis in human colorectal cancer. Oncoimmunology 2018, 7, e1470729. [CrossRef]

19. Bain, C.C.; Schridde, A. Origin, Differentiation, and Function of Intestinal Macrophages. Front. Immunol. 2018, 9, 2733. [CrossRef]

20. Laskin, D.L.; Sunil, V.R.; Gardner, C.R.; Laskin, J.D. Macrophages and tissue injury: Agents of defense or destruction? Annu. Rev. Pharmacol. Toxicol. 2011, 51, 267-288. [CrossRef]

21. Vannella, K.M.; Wynn, T.A. Mechanisms of Organ Injury and Repair by Macrophages. Annu. Rev. Physiol. 2017, 79, 593-617. [CrossRef] [PubMed]

22. Tauber, A.I. Metchnikoff and the phagocytosis theory. Nat. Rev. Mol. Cell Biol. 2003, 4, 897-901. [CrossRef] [PubMed]

23. van Furth, R. Macrophage activity and clinical immunology. Origin and kinetics of mononuclear phagocytes. Ann. N. Y. Acad. Sci. 1976, 278, 161-175. [CrossRef] [PubMed]

24. Epelman, S.; Lavine, K.J.; Randolph, G.J. Origin and functions of tissue macrophages. Immunity 2014, 41, 21-35. [CrossRef]

25. Gonzalez-Mejia, M.E.; Doseff, A.I. Regulation of monocytes and macrophages cell fate. Front. Biosci. (Landmark Ed) 2009, 14, 2413-2431. [CrossRef]

26. Sieweke, M.H.; Allen, J.E. Beyond stem cells: Self-renewal of differentiated macrophages. Science 2013, 342, 1242974. [CrossRef] 
27. Orkin, S.H.; Zon, L.I. Hematopoiesis: An evolving paradigm for stem cell biology. Cell 2008, 132, 631-644. [CrossRef]

28. Watanabe, S.; Alexander, M.; Misharin, A.V.; Budinger, G.R.S. The role of macrophages in the resolution of inflammation. J. Clin. Investig. 2019, 129, 2619-2628. [CrossRef]

29. Garceau, V.; Smith, J.; Paton, I.R.; Davey, M.; Fares, M.A.; Sester, D.P.; Burt, D.W.; Hume, D.A. Pivotal Advance: Avian colony-stimulating factor 1 (CSF-1), interleukin-34 (IL-34), and CSF-1 receptor genes and gene products. J. Leukoc. Biol. 2010, 87, 753-764. [CrossRef]

30. Martinez, F.O.; Gordon, S. The M1 and M2 paradigm of macrophage activation: Time for reassessment. F1000Prime Rep. 2014, 6, 13. [CrossRef]

31. Mills, C.D.; Kincaid, K.; Alt, J.M.; Heilman, M.J.; Hill, A.M. M-1/M-2 macrophages and the Th1/Th2 paradigm. J. Immunol. 2000, 164, 6166-6173. [CrossRef] [PubMed]

32. Murray, P.J. Macrophage Polarization. Annu. Rev. Physiol. 2017, 79, 541-566. [CrossRef] [PubMed]

33. Murray, P.J.; Allen, J.E.; Biswas, S.K.; Fisher, E.A.; Gilroy, D.W.; Goerdt, S.; Gordon, S.; Hamilton, J.A.; Ivashkiv, L.B.; Lawrence, T.; et al. Macrophage activation and polarization: Nomenclature and experimental guidelines. Immunity 2014, 41, 14-20. [CrossRef] [PubMed]

34. Thapa, B.; Lee, K. Metabolic influence on macrophage polarization and pathogenesis. BMB Rep. 2019, 52, 360-372. [CrossRef] [PubMed]

35. Tugal, D.; Liao, X.; Jain, M.K. Transcriptional control of macrophage polarization. Arterioscler. Thromb. Vasc. Biol. 2013, 33, 1135-1144. [CrossRef] [PubMed]

36. Lu, K.; Zhao, J.; Liu, W. Macrophage stimulating 1-induced inflammation response promotes aortic aneurysm formation through triggering endothelial cells death and activating the NF-kappaB signaling pathway. $J$. Recept. Signal Transduct. Res. 2020,1-9. [CrossRef]

37. Srivastava, M.; Saqib, U.; Naim, A.; Roy, A.; Liu, D.; Bhatnagar, D.; Ravinder, R.; Baig, M.S. The TLR4NOS1-AP1 signaling axis regulates macrophage polarization. Inflamm. Res. 2017, 66, 323-334. [CrossRef]

38. Schneider, A.; Weier, M.; Herderschee, J.; Perreau, M.; Calandra, T.; Roger, T.; Giannoni, E. IRF5 Is a Key Regulator of Macrophage Response to Lipopolysaccharide in Newborns. Front. Immunol. 2018, 9, 1597. [CrossRef]

39. Yunna, C.; Mengru, H.; Lei, W.; Weidong, C. Macrophage M1/M2 polarization. Eur. J. Pharmacol. 2020, 877, 173090. [CrossRef]

40. Chen, Y.; Song, Y.; Du, W.; Gong, L.; Chang, H.; Zou, Z. Tumor-associated macrophages: An accomplice in solid tumor progression. J. Biomed. Sci. 2019, 26, 78. [CrossRef]

41. Sica, A.; Mantovani, A. Macrophage plasticity and polarization: In vivo veritas. J. Clin. Investig. 2012, 122, 787-795. [CrossRef] [PubMed]

42. Cassol, E.; Cassetta, L.; Rizzi, C.; Alfano, M.; Poli, G. M1 and M2a polarization of human monocyte-derived macrophages inhibits HIV-1 replication by distinct mechanisms. J. Immunol. 2009, 182, 6237-6246. [CrossRef] [PubMed]

43. Ferrante, C.J.; Pinhal-Enfield, G.; Elson, G.; Cronstein, B.N.; Hasko, G.; Outram, S.; Leibovich, S.J. The adenosine-dependent angiogenic switch of macrophages to an M2-like phenotype is independent of interleukin-4 receptor alpha (IL-4Ralpha) signaling. Inflammation 2013, 36, 921-931. [CrossRef]

44. Li, H.; Jiang, T.; Li, M.Q.; Zheng, X.L.; Zhao, G.J. Transcriptional Regulation of Macrophages Polarization by MicroRNAs. Front. Immunol. 2018, 9, 1175. [CrossRef]

45. Yu, T.; Gan, S.; Zhu, Q.; Dai, D.; Li, N.; Wang, H.; Chen, X.; Hou, D.; Wang, Y.; Pan, Q.; et al. Modulation of M2 macrophage polarization by the crosstalk between Stat6 and Trim24. Nat. Commun. 2019, 10, 4353. [CrossRef]

46. Chistiakov, D.A.; Myasoedova, V.A.; Revin, V.V.; Orekhov, A.N.; Bobryshev, Y.V. The impact of interferonregulatory factors to macrophage differentiation and polarization into M1 and M2. Immunobiology 2018, 223, 101-111. [CrossRef] [PubMed]

47. Imtiyaz, H.Z.; Williams, E.P.; Hickey, M.M.; Patel, S.A.; Durham, A.C.; Yuan, L.J.; Hammond, R.; Gimotty, P.A.; Keith, B.; Simon, M.C. Hypoxia-inducible factor 2alpha regulates macrophage function in mouse models of acute and tumor inflammation. J. Clin. Investig. 2010, 120, 2699-2714. [CrossRef]

48. Chawla, A. Control of macrophage activation and function by PPARs. Circ. Res. 2010, 106, 1559-1569. [CrossRef] 
49. Lamkin, D.M.; Srivastava, S.; Bradshaw, K.P.; Betz, J.E.; Muy, K.B.; Wiese, A.M.; Yee, S.K.; Waggoner, R.M.; Arevalo, J.M.G.; Yoon, A.J.; et al. C/EBPbeta regulates the M2 transcriptome in beta-adrenergic-stimulated macrophages. Brain Behav. Immun. 2019, 80, 839-848. [CrossRef]

50. Atri, C.; Guerfali, F.Z.; Laouini, D. Role of Human Macrophage Polarization in Inflammation during Infectious Diseases. Int. J. Mol. Sci. 2018, 19, 1801. [CrossRef]

51. Dominguez-Soto, A.; Usategui, A.; Casas-Engel, M.L.; Simon-Fuentes, M.; Nieto, C.; Cuevas, V.D.; Vega, M.A.; Luis Pablos, J.; Corbi, A.L. Serotonin drives the acquisition of a profibrotic and anti-inflammatory gene profile through the 5-HT7R-PKA signaling axis. Sci. Rep. 2017, 7, 14761. [CrossRef] [PubMed]

52. Gershon, M.D.; Tack, J. The serotonin signaling system: From basic understanding to drug development for functional GI disorders. Gastroenterology 2007, 132, 397-414. [CrossRef] [PubMed]

53. Wu, H.; Denna, T.H.; Storkersen, J.N.; Gerriets, V.A. Beyond a neurotransmitter: The role of serotonin in inflammation and immunity. Pharmacol. Res. 2019, 140, 100-114. [CrossRef] [PubMed]

54. Orecchioni, M.; Ghosheh, Y.; Pramod, A.B.; Ley, K. Macrophage Polarization: Different Gene Signatures in M1(LPS+) vs. Classically and M2(LPS-) vs. Alternatively Activated Macrophages. Front. Immunol. 2019, 10, 1084. [CrossRef]

55. Morrison, C. Immuno-oncologists eye up macrophage targets. Nat. Rev. Drug Discov. 2016, 15, 373-374. [CrossRef]

56. Colegio, O.R.; Chu, N.Q.; Szabo, A.L.; Chu, T.; Rhebergen, A.M.; Jairam, V.; Cyrus, N.; Brokowski, C.E.; Eisenbarth, S.C.; Phillips, G.M.; et al. Functional polarization of tumour-associated macrophages by tumourderived lactic acid. Nature 2014, 513, 559-563. [CrossRef]

57. Chavez-Galan, L.; Olleros, M.L.; Vesin, D.; Garcia, I. Much More than M1 and M2 Macrophages, There are also CD169(+) and TCR(+) Macrophages. Front. Immunol. 2015, 6, 263. [CrossRef]

58. Movahedi, K.; Laoui, D.; Gysemans, C.; Baeten, M.; Stange, G.; Van den Bossche, J.; Mack, M.; Pipeleers, D.; In't Veld, P.; De Baetselier, P.; et al. Different tumor microenvironments contain functionally distinct subsets of macrophages derived from Ly6C(high) monocytes. Cancer Res. 2010, 70, 5728-5739. [CrossRef]

59. Ohtaki, Y.; Ishii, G.; Nagai, K.; Ashimine, S.; Kuwata, T.; Hishida, T.; Nishimura, M.; Yoshida, J.; Takeyoshi, I.; Ochiai, A. Stromal macrophage expressing CD204 is associated with tumor aggressiveness in lung adenocarcinoma. J. Thorac. Oncol. 2010, 5, 1507-1515. [CrossRef]

60. Qian, B.Z.; Pollard, J.W. Macrophage diversity enhances tumor progression and metastasis. Cell 2010, 141, 39-51. [CrossRef]

61. Casazza, A.; Laoui, D.; Wenes, M.; Rizzolio, S.; Bassani, N.; Mambretti, M.; Deschoemaeker, S.; Van Ginderachter, J.A.; Tamagnone, L.; Mazzone, M. Impeding macrophage entry into hypoxic tumor areas by Sema3A/Nrp1 signaling blockade inhibits angiogenesis and restores antitumor immunity. Cancer Cell 2013, 24, 695-709. [CrossRef] [PubMed]

62. Hagemann, T.; Wilson, J.; Burke, F.; Kulbe, H.; Li, N.F.; Pluddemann, A.; Charles, K.; Gordon, S.; Balkwill, F.R. Ovarian cancer cells polarize macrophages toward a tumor-associated phenotype. J. Immunol. 2006, 176, 5023-5032. [CrossRef] [PubMed]

63. Gao, L.; Zhang, W.; Zhong, W.Q.; Liu, Z.J.; Li, H.M.; Yu, Z.L.; Zhao, Y.F. Tumor associated macrophages induce epithelial to mesenchymal transition via the EGFR/ERK1/2 pathway in head and neck squamous cell carcinoma. Oncol. Rep. 2018, 40, 2558-2572. [CrossRef] [PubMed]

64. Linde, N.; Lederle, W.; Depner, S.; van Rooijen, N.; Gutschalk, C.M.; Mueller, M.M. Vascular endothelial growth factor-induced skin carcinogenesis depends on recruitment and alternative activation of macrophages. J. Pathol. 2012, 227, 17-28. [CrossRef]

65. Qian, B.Z.; Li, J.; Zhang, H.; Kitamura, T.; Zhang, J.; Campion, L.R.; Kaiser, E.A.; Snyder, L.A.; Pollard, J.W. CCL2 recruits inflammatory monocytes to facilitate breast-tumour metastasis. Nature 2011, 475, 222-225. [CrossRef]

66. Liu, C.Y.; Xu, J.Y.; Shi, X.Y.; Huang, W.; Ruan, T.Y.; Xie, P.; Ding, J.L. M2-polarized tumor-associated macrophages promoted epithelial-mesenchymal transition in pancreatic cancer cells, partially through TLR4/IL-10 signaling pathway. Lab. Investig. 2013, 93, 844-854. [CrossRef]

67. Fan, Q.M.; Jing, Y.Y.; Yu, G.F.; Kou, X.R.; Ye, F.; Gao, L.; Li, R.; Zhao, Q.D.; Yang, Y.; Lu, Z.H.; et al. Tumor-associated macrophages promote cancer stem cell-like properties via transforming growth factor-beta1-induced epithelial-mesenchymal transition in hepatocellular carcinoma. Cancer Lett. 2014, 352, 160-168. [CrossRef] 
68. Fu, X.T.; Dai, Z.; Song, K.; Zhang, Z.J.; Zhou, Z.J.; Zhou, S.L.; Zhao, Y.M.; Xiao, Y.S.; Sun, Q.M.; Ding, Z.B.; et al. Macrophage-secreted IL-8 induces epithelial-mesenchymal transition in hepatocellular carcinoma cells by activating the JAK2/STAT3/Snail pathway. Int. J. Oncol. 2015, 46, 587-596. [CrossRef]

69. Zheng, X.; Lu, G.; Yao, Y.; Gu, W. An Autocrine IL-6/IGF-1R Loop Mediates EMT and Promotes Tumor Growth in Non-small Cell Lung Cancer. Int. J. Biol. Sci. 2019, 15, 1882-1891. [CrossRef]

70. Masola, V.; Carraro, A.; Granata, S.; Signorini, L.; Bellin, G.; Violi, P.; Lupo, A.; Tedeschi, U.; Onisto, M.; Gambaro, G.; et al. In vitro effects of interleukin (IL)-1 beta inhibition on the epithelial-to-mesenchymal transition (EMT) of renal tubular and hepatic stellate cells. J. Transl. Med. 2019, 17, 12. [CrossRef]

71. Li, C.W.; Xia, W.; Huo, L.; Lim, S.O.; Wu, Y.; Hsu, J.L.; Chao, C.H.; Yamaguchi, H.; Yang, N.K.; Ding, Q.; et al. Epithelial-mesenchymal transition induced by TNF-alpha requires NF-kappaB-mediated transcriptional upregulation of Twist1. Cancer Res. 2012, 72, 1290-1300. [CrossRef] [PubMed]

72. Wei, H.; Liang, F.; Cheng, W.; Zhou, R.; Wu, X.; Feng, Y.; Wang, Y. The mechanisms for lung cancer risk of PM2.5: Induction of epithelial-mesenchymal transition and cancer stem cell properties in human non-small cell lung cancer cells. Environ. Toxicol. 2017, 32, 2341-2351. [CrossRef] [PubMed]

73. da Silva, I.L.; Montero-Montero, L.; Martin-Villar, E.; Martin-Perez, J.; Sainz, B.; Renart, J.; Toscano Simoes, R.; Soares Veloso, E.; Salviano Teixeira, C.; de Oliveira, M.C.; et al. Reduced expression of the murine HLA-G homolog Qa-2 is associated with malignancy, epithelial-mesenchymal transition and stemness in breast cancer cells. Sci. Rep. 2017, 7, 6276. [CrossRef] [PubMed]

74. Parameswaran, N.; Patial, S. Tumor necrosis factor-alpha signaling in macrophages. Crit. Rev. Eukaryot. Gene Express 2010, 20, 87-103. [CrossRef] [PubMed]

75. Storci, G.; Sansone, P.; Mari, S.; D’Uva, G.; Tavolari, S.; Guarnieri, T.; Taffurelli, M.; Ceccarelli, C.; Santini, D.; Chieco, P.; et al. TNFalpha up-regulates SLUG via the NF-kappaB/HIF1alpha axis, which imparts breast cancer cells with a stem cell-like phenotype. J. Cell. Physiol. 2010, 225, 682-691. [CrossRef]

76. Montfort, A.; Colacios, C.; Levade, T.; Andrieu-Abadie, N.; Meyer, N.; Segui, B. The TNF Paradox in Cancer Progression and Immunotherapy. Front. Immunol. 2019, 10, 1818. [CrossRef]

77. Brenner, D.; Blaser, H.; Mak, T.W. Regulation of tumour necrosis factor signalling: Live or let die. Nat. Rev. Immunol. 2015, 15, 362-374. [CrossRef]

78. Ham, B.; Fernandez, M.C.; D'Costa, Z.; Brodt, P. The diverse roles of the TNF axis in cancer progression and metastasis. Trends Cancer Res. 2016, 11, 1-27.

79. Manso, B.A.; Zhang, H.; Mikkelson, M.G.; Gwin, K.A.; Secreto, C.R.; Ding, W.; Parikh, S.A.; Kay, N.E.; Medina, K.L. Bone marrow hematopoietic dysfunction in untreated chronic lymphocytic leukemia patients. Leukemia 2019, 33, 638-652. [CrossRef]

80. Allegra, A.; Musolino, C.; Tonacci, A.; Pioggia, G.; Casciaro, M.; Gangemi, S. Clinico-Biological Implications of Modified Levels of Cytokines in Chronic Lymphocytic Leukemia: A Possible Therapeutic Role. Cancers (Basel) 2020, 12, 524. [CrossRef]

81. Dayer, J.M. From supernatants to cytokines: A personal view on the early history of IL-1, IL-1Ra, TNF and its inhibitor in rheumatology. Arthritis Res. Ther. 2018, 20, 101. [CrossRef] [PubMed]

82. Dinarello, C.A. An expanding role for interleukin-1 blockade from gout to cancer. Mol. Med. 2014, 20 (Suppl. 1), S43-S58. [CrossRef]

83. Garlanda, C.; Dinarello, C.A.; Mantovani, A. The interleukin-1 family: Back to the future. Immunity 2013, 39, 1003-1018. [CrossRef] [PubMed]

84. Li, Y.; Wang, L.; Pappan, L.; Galliher-Beckley, A.; Shi, J. IL-1beta promotes stemness and invasiveness of colon cancer cells through Zeb1 activation. Mol. Cancer 2012, 11, 87. [CrossRef] [PubMed]

85. Huang, Y.; Chen, R.; Zhou, J. E2F1 and NF-kappaB: Key Mediators of Inflammation-associated Cancers and Potential Therapeutic Targets. Curr. Cancer Drug Targets 2016, 16, 765-772. [CrossRef]

86. Kaler, P.; Godasi, B.N.; Augenlicht, L.; Klampfer, L. The NF-kappaB/AKT-dependent Induction of Wnt Signaling in Colon Cancer Cells by Macrophages and IL-1beta. Cancer Microenviron. 2009, 2, 69-80. [CrossRef]

87. Acuner Ozbabacan, S.E.; Gursoy, A.; Nussinov, R.; Keskin, O. The structural pathway of interleukin 1 (IL-1) initiated signaling reveals mechanisms of oncogenic mutations and SNPs in inflammation and cancer. PLoS Comput. Biol. 2014, 10, e1003470. [CrossRef]

88. Apte, R.N.; Krelin, Y.; Song, X.; Dotan, S.; Recih, E.; Elkabets, M.; Carmi, Y.; Dvorkin, T.; White, R.M.; Gayvoronsky, L.; et al. Effects of micro-environment- and malignant cell-derived interleukin-1 in carcinogenesis, tumour invasiveness and tumour-host interactions. Eur. J. Cancer 2006, 42, 751-759. [CrossRef] 
89. Takeuchi, H.; Katayama, I. Interleukin 1 (IL-1 alpha and IL-1 beta) induces differentiation/activation of B cell chronic lymphoid leukemia cells. Cytokine 1994, 6, 243-246. [CrossRef]

90. Arranz, L.; Arriero, M.D.M.; Villatoro, A. Interleukin-1beta as emerging therapeutic target in hematological malignancies and potentially in their complications. Blood Rev. 2017, 31, 306-317. [CrossRef]

91. Zhao, G.; Zhu, G.; Huang, Y.; Zheng, W.; Hua, J.; Yang, S.; Zhuang, J.; Ye, J. IL-6 mediates the signal pathway of JAK-STAT3-VEGF-C promoting growth, invasion and lymphangiogenesis in gastric cancer. Oncol. Rep. 2016, 35, 1787-1795. [CrossRef] [PubMed]

92. Yadav, A.; Kumar, B.; Datta, J.; Teknos, T.N.; Kumar, P. IL-6 promotes head and neck tumor metastasis by inducing epithelial-mesenchymal transition via the JAK-STAT3-SNAIL signaling pathway. Mol. Cancer Res. 2011, 9, 1658-1667. [CrossRef] [PubMed]

93. Dzaye, O.; Hu, F.; Derkow, K.; Haage, V.; Euskirchen, P.; Harms, C.; Lehnardt, S.; Synowitz, M.; Wolf, S.A.; Kettenmann, H. Glioma Stem Cells but Not Bulk Glioma Cells Upregulate IL-6 Secretion in Microglia/Brain Macrophages via Toll-like Receptor 4 Signaling. J. Neuropathol. Exp. Neurol. 2016, 75, 429-440. [CrossRef]

94. Silva, E.M.; Mariano, V.S.; Pastrez, P.R.A.; Pinto, M.C.; Castro, A.G.; Syrjanen, K.J.; Longatto-Filho, A. High systemic IL-6 is associated with worse prognosis in patients with non-small cell lung cancer. PLoS ONE 2017, 12, e0181125. [CrossRef] [PubMed]

95. Chen, Y.; Chen, L.; Yu, J.; Ghia, E.M.; Choi, M.Y.; Zhang, L.; Zhang, S.; Sanchez-Lopez, E.; Widhopf, G.F., 2nd; Messer, K.; et al. Cirmtuzumab blocks Wnt5a/ROR1 stimulation of NF-kappaB to repress autocrine STAT3 activation in chronic lymphocytic leukemia. Blood 2019, 134, 1084-1094. [CrossRef] [PubMed]

96. Buggins, A.G.; Patten, P.E.; Richards, J.; Thomas, N.S.; Mufti, G.J.; Devereux, S. Tumor-derived IL-6 may contribute to the immunological defect in CLL. Leukemia 2008, 22, 1084-1087. [CrossRef] [PubMed]

97. Yan, X.J.; Dozmorov, I.; Li, W.; Yancopoulos, S.; Sison, C.; Centola, M.; Jain, P.; Allen, S.L.; Kolitz, J.E.; Rai, K.R.; et al. Identification of outcome-correlated cytokine clusters in chronic lymphocytic leukemia. Blood 2011, 118, 5201-5210. [CrossRef]

98. Iyer, S.S.; Cheng, G. Role of interleukin 10 transcriptional regulation in inflammation and autoimmune disease. Crit. Rev. Immunol. 2012, 32, 23-63. [CrossRef]

99. Mosser, D.M.; Zhang, X. Interleukin-10: New perspectives on an old cytokine. Immunol. Rev. 2008, 226, 205-218. [CrossRef]

100. Chen, L.; Shi, Y.; Zhu, X.; Guo, W.; Zhang, M.; Che, Y.; Tang, L.; Yang, X.; You, Q.; Liu, Z. IL10 secreted by cancerassociated macrophages regulates proliferation and invasion in gastric cancer cells via cMet/STAT3 signaling. Oncol. Rep. 2019, 42, 595-604. [CrossRef]

101. Chen, Y.; Tan, W.; Wang, C. Tumor-associated macrophage-derived cytokines enhance cancer stem-like characteristics through epithelial-mesenchymal transition. OncoTargets Ther. 2018, 11, 3817-3826. [CrossRef] [PubMed]

102. Yang, L.; Dong, Y.; Li, Y.; Wang, D.; Liu, S.; Wang, D.; Gao, Q.; Ji, S.; Chen, X.; Lei, Q.; et al. IL-10 derived from M2 macrophage promotes cancer stemness via JAK1/STAT1/NF-kappaB/Notch1 pathway in non-small cell lung cancer. Int. J. Cancer 2019, 145, 1099-1110. [CrossRef] [PubMed]

103. Meng, F.; Li, C.; Li, W.; Gao, Z.; Guo, K.; Song, S. Interaction between pancreatic cancer cells and tumor-associated macrophages promotes the invasion of pancreatic cancer cells and the differentiation and migration of macrophages. IUBMB Life 2014, 66, 835-846. [CrossRef] [PubMed]

104. Fiorcari, S.; Maffei, R.; Audrito, V.; Martinelli, S.; Ten Hacken, E.; Zucchini, P.; Grisendi, G.; Potenza, L.; Luppi, M.; Burger, J.A.; et al. Ibrutinib modifies the function of monocyte/macrophage population in chronic lymphocytic leukemia. Oncotarget 2016, 7, 65968-65981. [CrossRef] [PubMed]

105. Alhakeem, S.S.; McKenna, M.K.; Oben, K.Z.; Noothi, S.K.; Rivas, J.R.; Hildebrandt, G.C.; Fleischman, R.A.; Rangnekar, V.M.; Muthusamy, N.; Bondada, S. Chronic Lymphocytic Leukemia-Derived IL-10 Suppresses Antitumor Immunity. J. Immunol. 2018, 200, 4180-4189. [CrossRef]

106. Wang, Y.; Liu, T.; Tang, W.; Deng, B.; Chen, Y.; Zhu, J.; Shen, X. Hepatocellular Carcinoma Cells Induce Regulatory T Cells and Lead to Poor Prognosis via Production of Transforming Growth Factor-beta1. Cell. Physiol. Biochem. 2016, 38, 306-318. [CrossRef]

107. Shen, W.; Tao, G.Q.; Zhang, Y.; Cai, B.; Sun, J.; Tian, Z.Q. TGF-beta in pancreatic cancer initiation and progression: Two sides of the same coin. Cell Biosci. 2017, 7, 39. [CrossRef]

108. Colak, S.; Ten Dijke, P. Targeting TGF-beta Signaling in Cancer. Trends Cancer 2017, 3, 56-71. [CrossRef] 
109. Haque, S.; Morris, J.C. Transforming growth factor-beta: A therapeutic target for cancer. Hum. Vaccines Immunother. 2017, 13, 1741-1750. [CrossRef]

110. Dong, M.; Blobe, G.C. Role of transforming growth factor-beta in hematologic malignancies. Blood 2006, 107, 4589-4596. [CrossRef]

111. Burger, J.A.; Tsukada, N.; Burger, M.; Zvaifler, N.J.; Dell'Aquila, M.; Kipps, T.J. Blood-derived nurse-like cells protect chronic lymphocytic leukemia B cells from spontaneous apoptosis through stromal cell-derived factor-1. Blood 2000, 96, 2655-2663. [CrossRef] [PubMed]

112. Yoshimura, T. The chemokine MCP-1 (CCL2) in the host interaction with cancer: A foe or ally? Cell. Mol. Immunol. 2018, 15, 335-345. [CrossRef] [PubMed]

113. Li, L.; Liu, Y.D.; Zhan, Y.T.; Zhu, Y.H.; Li, Y.; Xie, D.; Guan, X.Y. High levels of CCL2 or CCL4 in the tumor microenvironment predict unfavorable survival in lung adenocarcinoma. Thorac. Cancer 2018, 9, 775-784. [CrossRef] [PubMed]

114. Ding, M.; He, S.J.; Yang, J. MCP-1/CCL2 Mediated by Autocrine Loop of PDGF-BB Promotes Invasion of Lung Cancer Cell by Recruitment of Macrophages Via CCL2-CCR2 Axis. J. Interferon Cytokine Res. 2019, 39, 224-232. [CrossRef] [PubMed]

115. Chen, X.; Wang, Y.; Nelson, D.; Tian, S.; Mulvey, E.; Patel, B.; Conti, I.; Jaen, J.; Rollins, B.J. CCL2/CCR2 Regulates the Tumor Microenvironment in HER-2/neu-Driven Mammary Carcinomas in Mice. PLoS ONE 2016, 11, e0165595. [CrossRef]

116. Gandhi, V.; Balakrishnan, K. CCL2 in chronic lymphocytic leukemia: A macro in microenvironment? Leuk. Lymphoma 2012, 53, 1849-1850. [CrossRef]

117. Dal-Bo, M.; Bertoni, F.; Forconi, F.; Zucchetto, A.; Bomben, R.; Marasca, R.; Deaglio, S.; Laurenti, L.; Efremov, D.G.; Gaidano, G.; et al. Intrinsic and extrinsic factors influencing the clinical course of B-cell chronic lymphocytic leukemia: Prognostic markers with pathogenetic relevance. J. Transl. Med. 2009, 7, 76. [CrossRef]

118. Gine, E.; Martinez, A.; Villamor, N.; Lopez-Guillermo, A.; Camos, M.; Martinez, D.; Esteve, J.; Calvo, X.; Muntanola, A.; Abrisqueta, P.; et al. Expanded and highly active proliferation centers identify a histological subtype of chronic lymphocytic leukemia ("accelerated" chronic lymphocytic leukemia) with aggressive clinical behavior. Haematologica 2010, 95, 1526-1533. [CrossRef]

119. Tsukada, N.; Burger, J.A.; Zvaifler, N.J.; Kipps, T.J. Distinctive features of "nurselike" cells that differentiate in the context of chronic lymphocytic leukemia. Blood 2002, 99, 1030-1037. [CrossRef]

120. Filip, A.A.; Cisel, B.; Koczkodaj, D.; Wasik-Szczepanek, E.; Piersiak, T.; Dmoszynska, A. Circulating microenvironment of CLL: Are nurse-like cells related to tumor-associated macrophages? Blood Cells Mol. Dis. 2013, 50, 263-270. [CrossRef]

121. Boissard, F.; Fournie, J.J.; Laurent, C.; Poupot, M.; Ysebaert, L. Nurse like cells: Chronic lymphocytic leukemia associated macrophages. Leuk. Lymphoma 2015, 56, 1570-1572. [CrossRef] [PubMed]

122. Caligaris-Cappio, F. Role of the microenvironment in chronic lymphocytic leukaemia. Br. J. Haematol. 2003, 123, 380-388. [CrossRef] [PubMed]

123. Maffei, R.; Bulgarelli, J.; Fiorcari, S.; Bertoncelli, L.; Martinelli, S.; Guarnotta, C.; Castelli, I.; Deaglio, S.; Debbia, G.; De Biasi, S.; et al. The monocytic population in chronic lymphocytic leukemia shows altered composition and deregulation of genes involved in phagocytosis and inflammation. Haematologica 2013, 98, 1115-1123. [CrossRef] [PubMed]

124. Boissard, F.; Fournie, J.J.; Quillet-Mary, A.; Ysebaert, L.; Poupot, M. Nurse-like cells mediate ibrutinib resistance in chronic lymphocytic leukemia patients. Blood Cancer J. 2015, 5, e355. [CrossRef] [PubMed]

125. Choi, M.Y.; Kashyap, M.K.; Kumar, D. The chronic lymphocytic leukemia microenvironment: Beyond the B-cell receptor. Best Pract. Res. Clin. Haematol. 2016, 29, 40-53. [CrossRef] [PubMed]

126. Susek, K.H.; Karvouni, M.; Alici, E.; Lundqvist, A. The Role of CXC Chemokine Receptors 1-4 on Immune Cells in the Tumor Microenvironment. Front. Immunol. 2018, 9, 2159. [CrossRef]

127. Tokunaga, R.; Zhang, W.; Naseem, M.; Puccini, A.; Berger, M.D.; Soni, S.; McSkane, M.; Baba, H.; Lenz, H.J. CXCL9, CXCL10, CXCL11/CXCR3 axis for immune activation-A target for novel cancer therapy. Cancer Treat. Rev. 2018, 63, 40-47. [CrossRef]

128. Ocana, E.; Delgado-Perez, L.; Campos-Caro, A.; Munoz, J.; Paz, A.; Franco, R.; Brieva, J.A. The prognostic role of CXCR3 expression by chronic lymphocytic leukemia B cells. Haematologica 2007, 92, 349-356. [CrossRef] 
129. Burger, J.A.; Burger, M.; Kipps, T.J. Chronic lymphocytic leukemia B cells express functional CXCR4 chemokine receptors that mediate spontaneous migration beneath bone marrow stromal cells. Blood 1999, 94, 3658-3667. [CrossRef]

130. Burger, M.; Hartmann, T.; Krome, M.; Rawluk, J.; Tamamura, H.; Fujii, N.; Kipps, T.J.; Burger, J.A. Small peptide inhibitors of the CXCR4 chemokine receptor (CD184) antagonize the activation, migration, and antiapoptotic responses of CXCL12 in chronic lymphocytic leukemia B cells. Blood 2005, 106, 1824-1830. [CrossRef]

131. Ganghammer, S.; Gutjahr, J.; Hutterer, E.; Krenn, P.W.; Pucher, S.; Zelle-Rieser, C.; Johrer, K.; Wijtmans, M.; Leurs, R.; Smit, M.J.; et al. Combined CXCR3/CXCR4 measurements are of high prognostic value in chronic lymphocytic leukemia due to negative co-operativity of the receptors. Haematologica 2016, 101, e99-e102. [CrossRef]

132. Muller, G.; Hopken, U.E.; Lipp, M. The impact of CCR7 and CXCR5 on lymphoid organ development and systemic immunity. Immunol. Rev. 2003, 195, 117-135. [CrossRef] [PubMed]

133. Burkle, A.; Niedermeier, M.; Schmitt-Graff, A.; Wierda, W.G.; Keating, M.J.; Burger, J.A. Overexpression of the CXCR5 chemokine receptor, and its ligand, CXCL13 in B-cell chronic lymphocytic leukemia. Blood 2007, 110, 3316-3325. [CrossRef] [PubMed]

134. Cinamon, G.; Zachariah, M.A.; Lam, O.M.; Foss, F.W., Jr.; Cyster, J.G. Follicular shuttling of marginal zone B cells facilitates antigen transport. Nat. Immunol. 2008, 9, 54-62. [CrossRef]

135. Burger, J.A.; Quiroga, M.P.; Hartmann, E.; Burkle, A.; Wierda, W.G.; Keating, M.J.; Rosenwald, A. High-level expression of the T-cell chemokines CCL3 and CCL4 by chronic lymphocytic leukemia B cells in nurselike cell cocultures and after BCR stimulation. Blood 2009, 113, 3050-3058. [CrossRef] [PubMed]

136. Herishanu, Y.; Perez-Galan, P.; Liu, D.; Biancotto, A.; Pittaluga, S.; Vire, B.; Gibellini, F.; Njuguna, N.; Lee, E.; Stennett, L.; et al. The lymph node microenvironment promotes B-cell receptor signaling, NF-kappaB activation, and tumor proliferation in chronic lymphocytic leukemia. Blood 2011, 117, 563-574. [CrossRef] [PubMed]

137. Punt, J.; Stranford, S.A.; Jones, P.P.; Owen, J.A. Kuby Immunology, 8th ed.; Macmillan Learning: New York, NY, USA, 2019; Volume 1.

138. Cols, M.; Barra, C.M.; He, B.; Puga, I.; Xu, W.; Chiu, A.; Tam, W.; Knowles, D.M.; Dillon, S.R.; Leonard, J.P.; et al. Stromal endothelial cells establish a bidirectional crosstalk with chronic lymphocytic leukemia cells through the TNF-related factors BAFF, APRIL, and CD40L. J. Immunol. 2012, 188, 6071-6083. [CrossRef] [PubMed]

139. Schulz, A.; Toedt, G.; Zenz, T.; Stilgenbauer, S.; Lichter, P.; Seiffert, M. Inflammatory cytokines and signaling pathways are associated with survival of primary chronic lymphocytic leukemia cells in vitro: A dominant role of CCL2. Haematologica 2011, 96, 408-416. [CrossRef]

140. Liu, Y.; Wang, Y.; Yang, J.; Bi, Y.; Wang, H. ZAP-70 in chronic lymphocytic leukemia: A meta-analysis. Clin. Chim. Acta 2018, 483, 82-88. [CrossRef]

141. Lafarge, S.T.; Hou, S.; Pauls, S.D.; Johnston, J.B.; Gibson, S.B.; Marshall, A.J. Differential expression and function of CD27 in chronic lymphocytic leukemia cells expressing ZAP-70. Leuk. Res. 2015, 39, 773-778. [CrossRef]

142. Fayad, L.; Keating, M.J.; Reuben, J.M.; O’Brien, S.; Lee, B.N.; Lerner, S.; Kurzrock, R. Interleukin-6 and interleukin-10 levels in chronic lymphocytic leukemia: Correlation with phenotypic characteristics and outcome. Blood 2001, 97, 256-263. [CrossRef] [PubMed]

143. Couper, K.N.; Blount, D.G.; Riley, E.M. IL-10: The master regulator of immunity to infection. J. Immunol. 2008, 180, 5771-5777. [CrossRef] [PubMed]

144. Shaim, H.; Estrov, Z.; Harris, D.; Hernandez Sanabria, M.; Liu, Z.; Ruvolo, P.; Thompson, P.A.; Ferrajoli, A.; Daher, M.; Burger, J.; et al. The CXCR4-STAT3-IL-10 Pathway Controls the Immunoregulatory Function of Chronic Lymphocytic Leukemia and Is Modulated by Lenalidomide. Front. Immunol. 2017, 8, 1773. [CrossRef] [PubMed]

145. Abbaci, A.; Talbot, H.; Saada, S.; Gachard, N.; Abraham, J.; Jaccard, A.; Bordessoule, D.; Fauchais, A.L.; Naves, T.; Jauberteau, M.O. Neurotensin receptor type 2 protects B-cell chronic lymphocytic leukemia cells from apoptosis. Oncogene 2018, 37, 756-767. [CrossRef] [PubMed]

146. Talbot, H.; Saada, S.; Barthout, E.; Gallet, P.F.; Gachard, N.; Abraham, J.; Jaccard, A.; Troutaud, D.; Lalloue, F.; Naves, T.; et al. BDNF belongs to the nurse-like cell secretome and supports survival of B chronic lymphocytic leukemia cells. Sci. Rep. 2020, 10, 12572. [CrossRef] 
147. Boissard, F.; Tosolini, M.; Ligat, L.; Quillet-Mary, A.; Lopez, F.; Fournie, J.J.; Ysebaert, L.; Poupot, M. Nurse-like cells promote CLL survival through LFA-3/CD2 interactions. Oncotarget 2017, 8, 52225-52236. [CrossRef] [PubMed]

148. Messmer, B.T.; Messmer, D.; Allen, S.L.; Kolitz, J.E.; Kudalkar, P.; Cesar, D.; Murphy, E.J.; Koduru, P.; Ferrarini, M.; Zupo, S.; et al. In vivo measurements document the dynamic cellular kinetics of chronic lymphocytic leukemia B cells. J. Clin. Investig. 2005, 115, 755-764. [CrossRef]

149. Burger, J.A.; Ghia, P.; Rosenwald, A.; Caligaris-Cappio, F. The microenvironment in mature B-cell malignancies: A target for new treatment strategies. Blood 2009, 114, 3367-3375. [CrossRef] [PubMed]

150. Ponzoni, M.; Doglioni, C.; Caligaris-Cappio, F. Chronic lymphocytic leukemia: The pathologist's view of lymph node microenvironment. Semin. Diagn. Pathol. 2011, 28, 161-166. [CrossRef]

151. Damle, R.N.; Temburni, S.; Calissano, C.; Yancopoulos, S.; Banapour, T.; Sison, C.; Allen, S.L.; Rai, K.R.; Chiorazzi, N. CD38 expression labels an activated subset within chronic lymphocytic leukemia clones enriched in proliferating B cells. Blood 2007, 110, 3352-3359. [CrossRef]

152. Calissano, C.; Damle, R.N.; Hayes, G.; Murphy, E.J.; Hellerstein, M.K.; Moreno, C.; Sison, C.; Kaufman, M.S.; Kolitz, J.E.; Allen, S.L.; et al. In vivo intraclonal and interclonal kinetic heterogeneity in B-cell chronic lymphocytic leukemia. Blood 2009, 114, 4832-4842. [CrossRef] [PubMed]

153. Jaksic, O.; Paro, M.M.; Kardum Skelin, I.; Kusec, R.; Pejsa, V.; Jaksic, B. CD38 on B-cell chronic lymphocytic leukemia cells has higher expression in lymph nodes than in peripheral blood or bone marrow. Blood 2004, 103, 1968-1969. [CrossRef] [PubMed]

154. Deaglio, S.; Vaisitti, T.; Aydin, S.; Bergui, L.; D’Arena, G.; Bonello, L.; Omede, P.; Scatolini, M.; Jaksic, O.; Chiorino, G.; et al. CD38 and ZAP-70 are functionally linked and mark CLL cells with high migratory potential. Blood 2007, 110, 4012-4021. [CrossRef] [PubMed]

155. Deaglio, S.; Aydin, S.; Grand, M.M.; Vaisitti, T.; Bergui, L.; D’Arena, G.; Chiorino, G.; Malavasi, F. CD38/CD31 interactions activate genetic pathways leading to proliferation and migration in chronic lymphocytic leukemia cells. Mol. Med. 2010, 16, 87-91. [CrossRef]

Publisher's Note: MDPI stays neutral with regard to jurisdictional claims in published maps and institutional affiliations.

(C) 2020 by the authors. Licensee MDPI, Basel, Switzerland. This article is an open access article distributed under the terms and conditions of the Creative Commons Attribution (CC BY) license (http://creativecommons.org/licenses/by/4.0/). 